\title{
Use of ICT in Higher Education
}

\author{
Dr. Md. Mahmood Alam ${ }^{1 *}$
}

\section{ABSTRACT}

Information and Communication Technology (ICT), being the building blocks of modern society, has fundamentally changed the practices and procedures of nearly all forms of endeavor within academics and governance. The revolutionary change which is taking place in Information and Communication Technologies (ICTs) has dramatic effects on the way universities carry out their functions of teaching, learning and research, particularly on the creation, dissemination and application of knowledge. This requires a shift in the delivery and pedagogy used in the current education system. For India to emerge as knowledge super power of the world it is imperative to convert our demographic advantage into knowledge powerhouse by nurturing and honing our working population into knowledge enabled working population. Thus ICT integration is a crying need for capacity building efforts of educational institutions. Research has suggested that using ICT in instruction enables students to take a more active role in their learning rather than their more traditional role of passive observer and listener. With all parameters it acts as a change agent in education and society by promoting a proper balance between content generations and research in critical areas. Therefore it is pertinent to pay attention to the ICT implementation in educational system for imparting easily accessible, affordable and quality higher education.

\section{Keywords: ICT, Higher Education}

Education is the driving force of economic and social development in any country (Cholin, 2005; Mehta and Kalra, 2006). Several factors which have strengthened and encouraged moves to adopt ICTs into classrooms and learning settings included a growing need to explore efficiencies in terms of program delivery, the opportunities for flexible delivery provided by ICTs (e.g. Oliver \& Short, 1997); the capacity of technology to provide support for customized educational programs to meet the needs of individual learners (e.g. Kennedy \& Mc Naught, 1997); and the growing use of the Internet and WWW as tools for information access and communication (e.g. Oliver \& Towers, 1999). As we move into the 21st century, these factors and many others are bringing strong forces to bear on the adoption of ICTs in education in

\footnotetext{
${ }^{1}$ Assistant Professor, MANUU College of Teacher Education, Sambhal, U.P., India *Responding Author

(C) 2016, M Alam; licensee IJIP. This is an Open Access Research distributed under the terms of the Creative Commons Attribution License (http://creativecommons.org/licenses/by/2.0), which permits unrestricted use, distribution, and reproduction in any Medium, provided the original work is properly cited.
} 


\section{Use of ICT in Higher Education}

general and higher education in particular. It is only through education and the integration of ICT in education that one can teach students to be participants in the growth process in this era of rapid change. ICT can be used as a tool in the process of education in the following ways:

1. Informative tool: It provides vast amount of data in various formats such as audio, video, documents.

2. Situating tool: It creates situations, which the student experiences in real life. Thus, simulation and virtual reality is possible.

3. Constructive tool: To manipulate the data and generate analysis.

4. Communicative tool: It can be used to remove communication barriers such as that of space and time (Lim and Chai, 2004).

The use of ICT offers powerful learning environments and can transform the learning and teaching process so that students can deal with knowledge in an active, self directed and constructive way (Volman \& Van Eck, 2001; de Corte et al., 2003). The innovative use of ICT is believed to significantly strengthen higher education system and addresses the three fundamental challenges of access, equity and quality.

\section{ROLE OF ICT IN HIGHER EDUCATION}

Introduction of ICTs in the higher education has profound implications for the whole education process ranging from investment to use of technologies in dealing with key issues of access, equity, management, efficiency, pedagogy, quality, research and innovation. ICT applications provide institutions with a competitive edge by offering enhanced services to students and faculty, driving greater efficiencies and creating enriched learning experiences.

\section{ICT in Teaching and Learning}

While for higher education sector is planned to build a knowledge repository of multidisciplinary subjects, as a strategy to counter the shortage of faculty in higher education, EDUSAT will be used to share the available expertise through modular programmes. This will be done by networking institutions, creation of virtual laboratories, creation of database, access to expert lectures and technological developments in industries and research organizations etc. Teaching and learning can further be improved by replacing of conventional teaching instead of the usual age old method of chalk and talk for teaching by innovative methods like power point presentations and animations, modeling and simulations, video clips and using AV aids, LCD projectors etc. This enhances the learning ability of the student and also helps the teacher to elaborate the difficult concepts effectively within a short time span.

\section{ICT in Administration}

ICT in administration of educational institutions play a major role in efficient utilization of existing resources and simplifies the administration tasks (e.g. in student administration, staff administration, general administration etc.) by reducing the paper work and replaces the manual maintenance of record keeping to electronic maintenance of records which helps in easy retrieval 


\section{Use of ICT in Higher Education}

of any information of students, staff and general with in a fraction of seconds can access the required information.

\section{ICT in Research}

Integration of ICT in higher education enhances the quality of research work and more number of individuals enrolled in the research work in various fields. ICT facilitates the links across the world in all subject matter and made social networking. It saves time, money and effort to the researchers in their research studies. The collection and analysis of large data becomes easier through the availability of various software. The unprecedented growth in bandwidth and computing power provide opportunities for download huge amount of data and can perform complex computations on them in a fast manner to get an accurate and reliability of data.

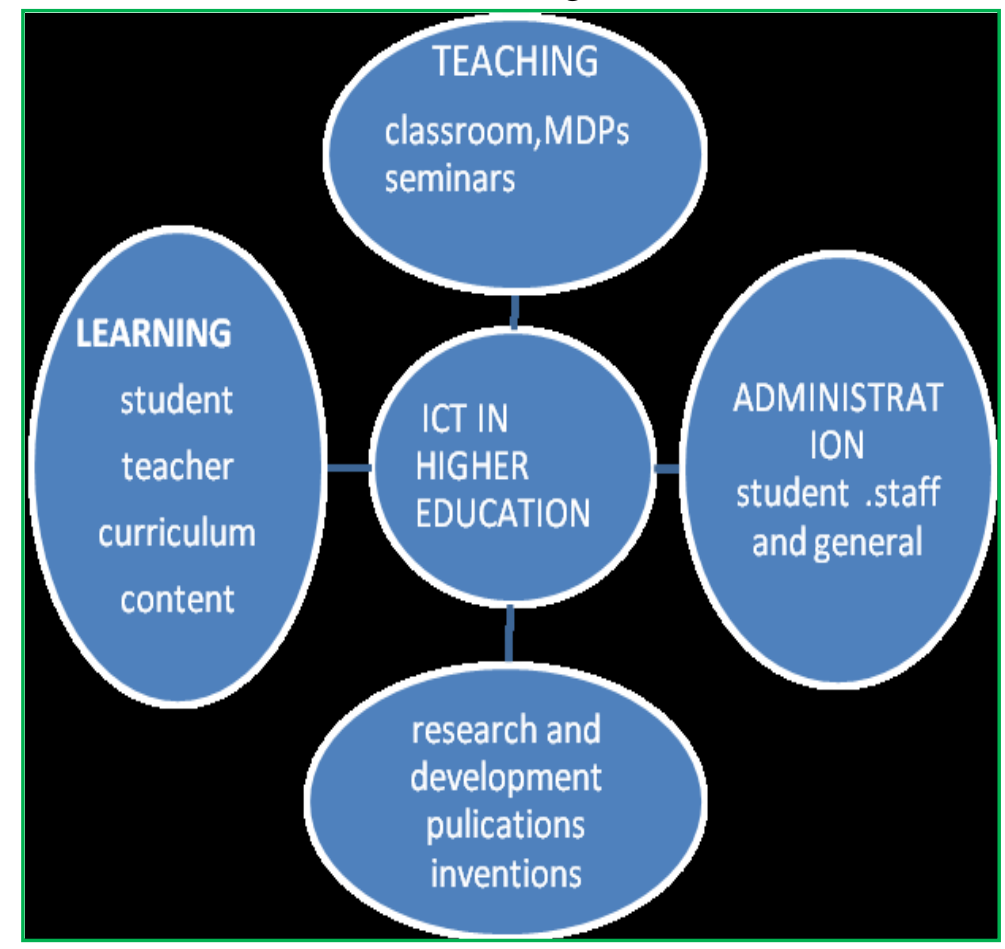

\section{ICT as a Change Agent in Higher Education}

The evolution of higher education in India combined with the need to sustain and be competitive in a global scenario requires decisions to be taken quickly and effectively. This has enhanced the scope and complexity of administration, thus making it necessary to adopt different methods of higher education administration

1.The increasing student population in higher education accelerated the need for ICTs to process, store and retrieve data in a fast, systemic and accurate fashion. The focus of e-administration in higher education is on the creation of an efficient electronic administration by handling existing resources economically. According to Sanat Kaul (2006), the usage of ICT in higher education institutions starts from the early stages of receiving e-notifications regarding admission, course schedules, and billing procedures and continues till the end of the course including online publication of results

(C) The International Journal of Indian Psychology, ISSN 2348-5396 (e) | ISSN: 2349-3429 (p) | 164 


\section{Use of ICT in Higher Education}

2.The concept of moving the traditional classroom of desks, notebooks, pencils, and blackboard to an online forum of computers, software, and the internet intimidates many teachers who are accustomed to the face-to-face interaction of the traditional classroom(Sukanta Sarkar 2012)

3.ICT change the concept of teacher centered learning to student centered learning and teachers acts as coaches, mentors and knowledge facilitators and the learning environment focus on a real time problem solving methods

4.Learning is an active process of constructing knowledge rather than acquiring knowledge and that instruction is the process by which this knowledge construction is supported rather than a process of knowledge transmission (Duffy \& Cunningham, 1996).

5.ICTs make possible asynchronous learning, or learning characterized by a time lag between the delivery of instruction and its reception by learners. Online course materials, for example, may be accessed 24 hours a day, 7 days a week. Teachers and learners no longer have to rely solely on printed books and other materials in physical media housed in libraries (and available in limited quantities) for their educational needs. With the internet and the World Wide Web, a wealth of learning materials in almost every subject and in a variety of media can now be accessed from anywhere at any time of the day and by an unlimited number (Sukantha Sarkar 2012)

Information technology changes the concept of traditional method of research work and made the researchers to do more feasibility and reliability studies. With the evolution of ICT researchers can complete their research work in a short period of time and motivates many upcoming researchers to handle more research works.

\section{ICT as a Change agent in Society}

The last two decades have seen a critical examination of the role higher education institutions in economic growth and social development. In addition to teaching and research, contributing to regional economic growth through innovation is now perceived as the third role of universities. The university-industry-government linkage as a triple-helix model through which effective transfer of technologies leads to economic growth (Balasubrmanyam 2009).

1. The developmental role of higher education institutions can be seen from its initiatives and impacts in addressing social issues such as poverty, inequality, gender, environment and empowering the poor and marginalized sections of the society to play a major role in the developmental process.

2. The government is proposing the creation of a high speed knowledge network providing connectivity across education institutions. The connectivity should be provided to supplement the current networking initiatives being undertaken, intra and inter- disciplinary networks to enhance research collaboration. This can also be supplemented by creation of online communities of practice

3. ICT promotes the generation of new business and job opportunities for a large number of population. This will generate the economy, reduces unemployment and enhances the standard of living of society.

(C) The International Journal of Indian Psychology, ISSN 2348-5396 (e)| ISSN: 2349-3429 (p) | 165 


\section{Use of ICT in Higher Education}

4. ICT is a connecting agent as it connects the people across world through various devices like pager, faxes, mobiles, emails and social networks etc. This enables the people to utilize the resources as and when needed with the changing environment and develops new trends in the society.

5. ICT adds value in the organization and management of learning institutions. The internet is a driving force for much development and innovation in individuals, business organizations, educational institutions and society at large.

\section{BARRIERS TO THE IMPLEMENTATION OF ICT IN EDUCATION}

Although the government is committed to implementing ICT in education, the process is hindered by a number of barriers. The barriers are categorized as external (first-order) or internal (second order) (Keengwe, Onchwari et al. 2008).

\section{ICT Supported Infrastructure and Lack of Resources}

The effective use of ICT would require the availability of equipments which are not available in all the educational institutions. Besides, ICT requires up-to-date hardware and software. Highspeed internet connection is another prerequisite for integrating ICT into the teaching-learning situation. But unfortunately internet access is very poor.

\section{Insufficient Funds}

Effective implementation of technology into education systems involves substantial funding. ICT-supported hardware, software, internet, audio visual aids, teaching aids and other accessories demand huge funds. Afshari, Bakar \& Su-Luan et al. (2009) state that efficient and effective use of technology depends on the availability of hardware and software and the equity of access to resources by teachers, students an administrative staff. These costs are in most cases substantially high and cannot be provided by the stake holders.

\section{Political Factors}

Sharma (2003) states that the most notable of the barriers to the use of ICT in education in developing countries seems to be the political will of the people in the corridors of power. The allocation of sufficient funds for the educational sector and ICT does not seem to be very attractive to the leaders. If the political leaders favour the technology, it will bloom. It is observed that the vision and mission of the government changes after change of power at the centre as they fix priority to some other sectors in the form of fund allocation and its policy implementation.

\section{Social and Cultural Factors}

Mc Donald (2001) has suggested that the emergence of English as a dominant language of science, technology, business and interactional relations, as well as education and training, would ensure the availability of globally useable knowledge products. This in turn will also offer more opportunities for a wide range of choices in educational and training courses. But currently language seems to be one of the major social barriers to the use of ICT, particularly, in rural areas. Wims and Lawler (2008) found that lack of developmentally-appropriate software (DAS) is one of the difficulties faced by teachers and students. 


\section{Use of ICT in Higher Education}

\section{Corruption}

Corruption is one of the strong barriers to the implementation of ICT in education. The misuse of government funds which could have been used to develop other sectors like the integration of ICT in education is channeled in other directions i.e. few people benefit from those funds by pocketing all the money (Kessy et al, 2006). The budget for the newer technology is misused due to corruption at every level in the administration. Huge budgets are passed to buy modern teaching and learning materials for the improvement of the teaching and learning process, but in the end only minor improvements are found in the overall technical and vocational sector.

\section{Teachers' Attitudes and Beliefs about ICT}

Teachers' attitudes have been found to be major predictors of the use of new technologies in instructional settings (Almusalam, 2001). Mumtaz (2000) states that teacher' beliefs about teaching and learning with ICT are central to integration. To be successful in computer use and integration, teachers need "to engage in conceptual change regarding their beliefs about the nature of learning, the role of the student, and their role as teacher"' (Niederhauser et al. 1999, p. 157). Hence the successful use of ICT into classroom largely depends on teachers' attitudes and belief relating to these. Therefore, if teachers want to successfully use technology in their classes, they need to possess positive attitudes to the use of technology. Such attitudes are developed when teachers are sufficiently comfortable with technology and are knowledgeable about its use (Afshari et al, 2009).

\section{Lack of Knowledge and Skill}

According to Pelgrum (2001), the success of educational innovations depends largely on the skills and knowledge of teachers. Teachers' lack of knowledge and skills is one of the main hindrances to the use of ICT in education both for the developed and underdeveloped countries (Mamun, \& Tapan, 2009; Pelgrum, 2001). Integrating technology in the curriculum requires knowledge of the subject area, an understanding of how students learn and a level of technical expertise (Morgan 1996). Moreover, Berner (2003) found that the faculty's belief in their computer competence was the greatest predictor of their use of computers in the classroom. Therefore, lack of knowledge regarding the use of ICT and lack of skill on ICT tools and software have also limited the use of ICT tools in teaching learning.

\section{Lack of Time}

Teachers are burdened with heavy workload. In these circumstances teachers don't have time to design, develop and incorporate technology into the teaching learning situation (Beggs, 2000; Ihmeideh, 2009). Research studies reported lack of time as one of the biggest constraints to the integration of ICT into the teaching learning. Teachers need time to learn how to use the hardware and software, time to plan, and time to collaborate with other teachers. They also need time to develop and incorporate technology into their curriculum. Some teachers are unable to make appropriate use of technology in their own classrooms, while others are unwilling to try because of anxiety, lack of interest, or lack of motivation (Duhaney 2001). 


\section{Use of ICT in Higher Education}

\section{BENEFITS OF INTEGRATING ICT IN HIGHER EDUCATION}

The adoption and integration of ICTs in education have a positive impact on teaching, learning, and research. In addition, it increases flexibility; provide the rich environment and motivation for teaching learning process which have a profound impact on the process of learning by offering new possibilities for learners and teachers. These possibilities can have an impact on student performance and achievement. The various benefits of ICT in education to various stakeholders are summarized as follows:

\section{(a) To Student}

- Increased access,

- $\quad$ Flexibility of content and delivery,

- Combination of work and education,

- $\quad$ Learner-centred approach,

- $\quad$ Higher quality of education and new ways of interaction.

(b) Employers

- $\quad$ High quality, cost effective professional development in the workplace,

- Upgrading of employee skills, increased productivity,

- $\quad$ Development of a new learning culture,

- $\quad$ Sharing of costs and of training time with the employees,

- Increased portability of training.

(c) Governments

- Increase the capacity and cost effectiveness of education and training systems,

- To reach target groups with limited access to conventional education and training,

- To support and enhance the quality and relevance of existing educational structures,

- To ensure the connection of educational institutions and curricula to the emerging networks and information resources,

- To promote innovation and opportunities for lifelong learning.

\section{RECOMMENDATIONS}

In the light of the above discussion, the paper suggests the following recommendations for improving on the current situation:

1. Effective implementation of ICT in education requires commitment from the stake holders. That is, all the stakeholders and responsible authorities including teachers and other staff should be aware of the importance of technology in developing student's learning and should strive to overcome the barriers, so that students can benefit effectively from this ICT. Therefore, a clear vision of ICT integration in institutions in general and higher institutions in particular should be given due consideration to promotes effective use of ICT in the classroom.

2. Lacks of resources results in lack of ICT integration, which in turn results in lack of sufficient computer experience for both pupils and teachers (Rosen \& Weil, 1995). The

(c) The International Journal of Indian Psychology, ISSN 2348-5396 (e)| ISSN: 2349-3429 (p) | 168 


\section{Use of ICT in Higher Education}

stakeholders and school authorities need to be provided with adequate facilities and resources for effective implementation of ICT.

3. The government should formulate policies for encouraging girls with respect to the adoption of ICT. Without proper empowering of women, it is not possible to implement ICT in education. Sharma (2003) states that the policy-makers must pay more attention to accommodate all sectors (and those excluded also like rural communities, women and disabled) while planning for adoption of ICT.

4. Effective implementation of ICT in educational institutions requires in-depth professional development. Attention needs to be given to in-service, pre- service and newly appointed teachers to acquaint them with the role of technology in educational settings and to train them on how to prepare and use ICT competently.

5. To introduce and implement computers in the classroom effectively, changing teachers' negative attitudes is essential. Therefore, if teachers want to successfully use technology in their classes, they need to possess a positive attitude to the use of technology. Such an attitude is developed when teachers are sufficiently comfortable with technology and are knowledgeable about its use (Harrison \& Rainer, 1992; Afshari et al, (2009).

\section{CONCLUSION}

Higher education institutions are important actors in the community and can be perceived as models for society in the pursuit of sustainable development. Higher education should not only critically reflect on learning environments and learning processes for students, they should also reflect on their role in creating an infrastructure that supports and enhances lifelong learning processes. The wide adoption of ICT calls for mindsets and skill sets that are adaptive to change. ICT integration in higher education brings a change in student and teacher learning behavior and develops higher order skills such as collaborating across time and place and solving complex real world problems. To gain the optimum impact of ICT in education, certain issues: why teachers integrate technology; how ICT implementation could be effective; what the requirements are to achieve effective ICT implementation need to be addressed. Research studies have indicated that one of the key determinants of whether ICT implementation is successful is the teachers, particularly, teachers' knowledge. Teacher has to adapt continuous professional development in the educational uses of technology. There needs to be shared vision among the various stakeholders and a collaborative approach should be adopted. Care should be taken to influence the attitudes and beliefs of all the stakeholders. Also proper controls should be ensured so that accountability, quality assurance, accreditation and consumer protection are taken care of. ICT enabled education will ultimately lead to the democratization of education.

\section{Acknowledgement}

We would like to show my sincere gratitude to Dr. Nishat Anjum, Principal, Presidency College of Education for Girls, Hyderabad, (Affiliated to Osmania University) for their encouragement, guidance and support.

(C) The International Journal of Indian Psychology, ISSN 2348-5396 (e)| ISSN: 2349-3429 (p) | 169 


\section{Use of ICT in Higher Education}

\section{REFERENCES}

Afshari et al. (2009), "Factors affecting teachers' use of information and communication technology", International Journal of Instruction, 2(1), 77-104.

Almusalam, (2001), "Factors related to the use of computer technologies for professional tasks by business and administration teachers at Saudi technical colleges", Pro Quest Digital Dissertations (UMI No. AAT 3011019).

Balasubrmanyam, (2009), "Background paper from the Commonwealth of Learning for the UNESCO World Conference on Higher Education”, Paris.

Beggs, T. A. (2000), "Influences and barriers to the adoption of instructional technology", In Proceedings of the mid-south instructional technology conference. Retrieved April 28, 2011, from http://www.mtsu.edu/\%7Eitconf/proceed00/beggs/beggs.htm.

Berner, J. E. (2003), “A Study of Factors That May Influence Faculty in Selected Schools of Education in the Commonwealth of Virginia to Adopt Computers in the Classroom”, Pro Quest Digital Dissertations (UMI No. AAT 3090718).

Cholin, V. S. (2005), "Study of the application of information technology for effective access to resources in Indian university libraries", The International Information \& Library Review, 37(3), 189-197.

De Corte et al. (2003), "Powerful learning environments: unraveling basic components and dimensions”, Oxford: Pergamon/Elsevier.

Duffy, T., \& Cunningham, D. (1996), "Constructivism: Implications for the design and delivery of instruction", Handbook of Research for Educational Telecommunications and Technology, New York: MacMillan, 170-198.

Duhaney, D. C. (2001), “Teacher Education: Preparing Teachers to Integrate Technology”, International Journal of Instructional Media, 28(1), 23-30.

Ihmeideh, F. M. (2009), "Barriers to the Use of Technology in Jordanian Pre-School Settings", Technology, Pedagogy and Education, 18(3), 325-341.

Kennedy, D. \& Mc Naught, C. (1997), "Design Elements for Interactive Multimedia”, Australian Journal of Educational Technology, 13(1), 1-22.

Keengwe, J., G. Onchwari, et al. (2008), "Computer Technology Integration and Student Learning: Barriers and Promise”, Journal of Science Education and Technology, 17(6), 560-565.

Kessy et al, 2006, "The Reasons for under use of ICT in education: In the Context of Kenya, Tanzania and Zambia”, Paper presented at the 4th IEEE International Workshop on Technology for Education in Developing Countries, Iringa, Tanzania.

Lim, C. P. \& Chai, C.S. (2004), "An activity-Theoretical Approach to Research of ICT Integration in Singapore Schools: Orienting Activities and Learner Autonomy", Computers \& Education, 43 (3), 215-236.

Mamun, A. \& Tapan, S.M. (2009), "Using ICT in Teaching-Learning at the Polytechnic Institutes of Bangladesh: Constraints and Limitations”, Teacher's World-Journal of Education and Research, 33-34, 207-217. 


\section{Use of ICT in Higher Education}

Mehta, S. \& Kalra, M. (2006), "Information and Communication Technologies: A Bridge for Social Equity and Sustainable Development in India”, The International Information \& Library Review, 38(3), 147-160

Morgan T. (1996), “Using Technology to Enhance Learning: Changing the Chunks”, Learning and Leading with Technology, 23(5), 49-51.

Mumtaz, S. (2000), "Factors Affecting Teachers' Use of Information and Communications Technology: A review of the Literature”, Journal of Information Technology for Teacher Education, 9(3), 319-342.

(Niederhauser et al. (1999), "Exploring Teaching, Learning, and Instructional Reform in an Introductory Technology Course”, Journal of Technology and Teacher Education, 7(2), 153-172.

Oliver, R. \& Short, G. (1996), "The Western Australian Telecentres Network: A Model for Enhancing Access to Education and Training in Rural Areas”, International Journal of Educational Telecommunications, 2(4), 311-328.

Oliver, R. \& Towers, S. (2000), "Benchmarking ICT Literacy in Tertiary Learning Settings. In R. Sims, M. O’Reilly \& S. Sawkins (Eds). Learning to choose: Choosing to learn. Proceedings of the 17th Annual ASCILITE Conference, Lismore, NSW: Southern Cross University Press, 381-390.

Pelgrum, W.J. (2001), "Obstacles to the Integration of ICT in Education: Results from a Worldwide Educational Assessment”, Computers \& Education, 37, 163- 178.

Rosen, L. D. \& Weil, M. M. (1995), "Computer Availability, Computer Experience, and Technophobia among Public School Teachers", Computers in Human Behavior, 11(1), 9-31.

Sanat Kaul (2006), "Higher Education in India: Seizing the Opportunity", (ICIER Working Paper No. 179), New Delhi: Indian Council for Research on International Economic Relations, (http://www.icrier.org).

Sharma, R. C. (2003), "Barriers in Using Technology for Education in Developing Countries", Information Technology: Research and Education, Proceedings ITRE2003, International Conference on.

Sukanta, S. (2012), "Role of ICT in Higher Education for the 21st Centuary”, Science Probe, 1, 30-41.

Volman, M., \& Van Eck, E. (2001), “Gender Equity and Information Technology in Education: The Second Decade”, Review of Educational Research, 71(4), 613-634.

Wims, P., \& Lawler, M. (2008), "Investing in ICTs in Educational Institutions in Developing Countries: An Evaluation of their Impact in Kenya', International Journal of Education and Development Using Information and Communication.

How to cite this article: M Alam (2016), Use of ICT in Higher Education, International Journal of Indian Psychology, Volume 3, Issue 4, No. 68, ISSN:2348-5396 (e), ISSN:2349-3429 (p), DIP:18.01.208/20160304, ISBN:978-1-365-39398-3

(C) The International Journal of Indian Psychology, ISSN 2348-5396 (e)| ISSN: 2349-3429 (p) | 171 